\title{
Tribenzotriquinacenes bearing three peripheral or bridgehead urea groups stretched into the 3-D space
}

\author{
Jörg Tellenbröker and Dietmar Kuck ${ }^{*}$
}

\author{
Full Research Paper \\ Address: \\ Department of Chemistry, Bielefeld University, Universitätsstraße 25, \\ D-33615 Bielefeld, Germany \\ Email: \\ Dietmar Kuck* - dietmar.kuck@uni-bielefeld.de \\ * Corresponding author \\ Keywords: \\ convex-concave structures; polycyclic compounds; supramolecular \\ chemistry; tribenzotriquinacenes; urea derivatives
}

\begin{abstract}
The syntheses of tribenzotriquinacenes (TBTQ) bearing three phenylurea groupings at either the arene periphery or at the benzhydrylic bridgeheads of the rigid, convex-concave, $C_{3 v}$-symmetrical molecular framework are reported. ${ }^{1} \mathrm{H}$ NMR data point to supramolecular aggregation of these TBTQ derivatives in low-polarity solvents.
\end{abstract}

\section{Introduction}

In the course of our extended research on polyfunctionalized derivatives of tribenzotriquinacene (TBTQ, 1) and some hydrocarbon congeners $\mathbf{2}-\mathbf{4}$, which provide a great variety of convex-concave molecular building blocks [1-7], we focused our attention on the synthesis of TBTQ derivatives 5-7 with three urea units located at the molecular periphery (Figure 1). Owing to the rigidity of their molecular framework, these compounds were considered of potential interest for the formation of supramolecular aggregates consisting of two or more multiply hydrogen-bonded TBTQ units. Research on the formation and chemical properties of host-guest compounds bearing urea units as linker groups has become an exciting field of scientific interest over the past few decades [8-15]. For example, cone-like building blocks such as those based on calix[4]arenes and calix[6] arenes bearing urea groups at their lower rims have been used for the generation of multi-hydrogen bonded dimers $[8,9]$. Therefore, the TBTQ framework, with its close similarity to that of the cyclotribenzylenes and the cyclotriveratrylenes [16-19], should constitute a promising substrate for such studies. In the present paper, we wish to report the facile access to TBTQs that bear three phenylurea groups directed into the 3-D space in well controlled orientations. Some observations that point to non-covalent aggregation of these novel molecules are also reported. 


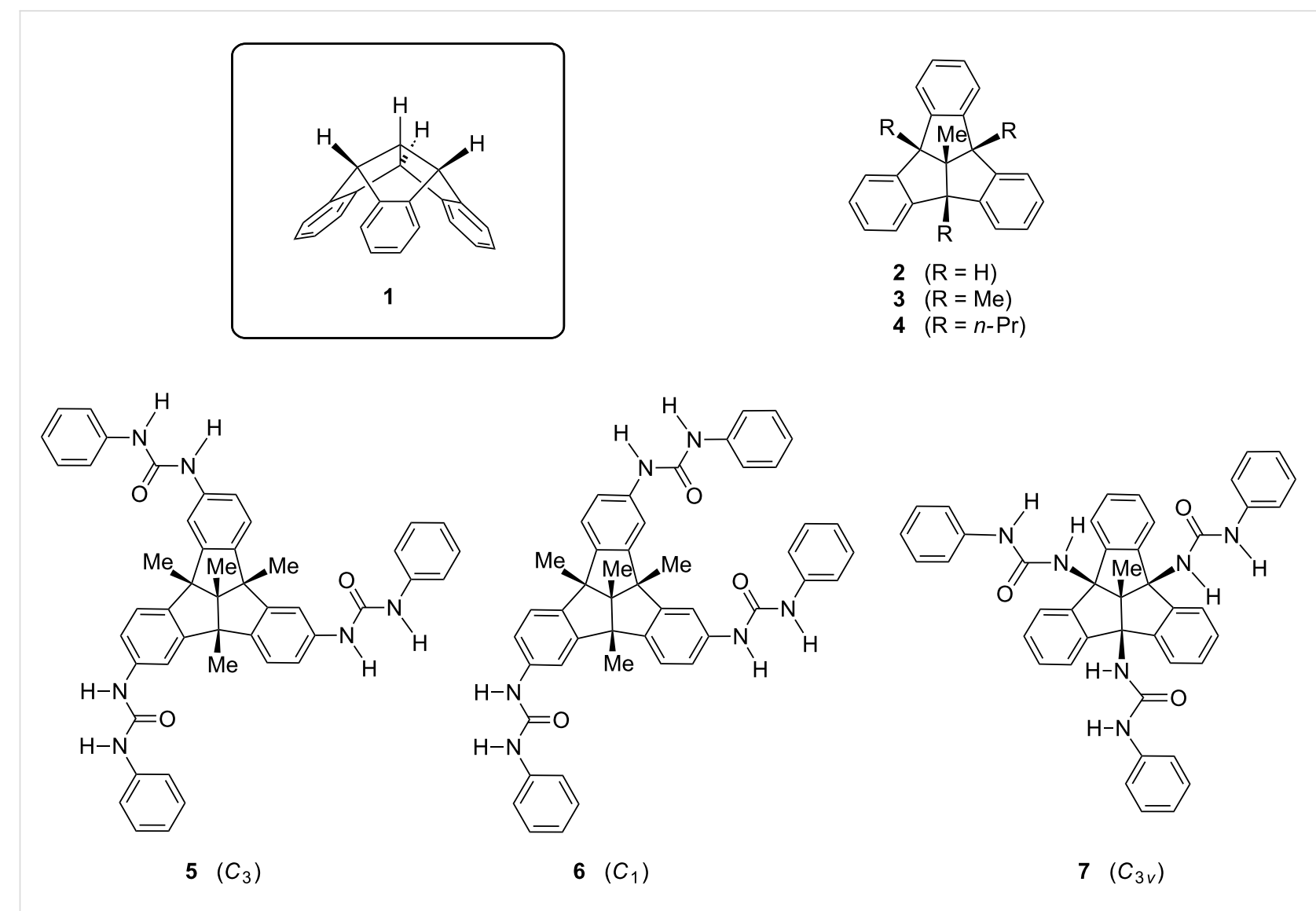

Figure 1: Parent TBTQ 1, three bridgehead-alkylated congeners 2-4, and three TBTQ tris-urea derivatives 5-7 bearing the functional groups in three different spatial orientations.

\section{Results and Discussion}

As shown earlier, introduction of six amino groups at the periphery of the TBTQ skeleton is achievable by nitration with nitric acid (100\%) and sulfuric acid (98\%) followed by reduction [20]. However, this holds true only for TBTQ derivatives with alkyl groups at the benzhydrylic bridgehead positions, such as the tetramethyl derivative 3 [20] and the related tripropyl analog 4 [5,7]. The monomethyl derivative 2 decomposes under these conditions. By contrast, threefold nitration of the arene periphery, leading to single functionalization at the outer positions of each of the three benzene rings, was achieved by use of sodium nitrate in trifluoroacetic acid [21]. As shown in Scheme 1, this method allowed us to convert the tetramethyl derivate 3 into a mixture of the $C_{3}$-symmetrical compound $\mathbf{8}$ and the $C_{1}$-symmetrical isomer 9 in apparently quantitative yield. More recently, this method was also successfully applied to the analogous nitration of compound 2 [22].

Our attempts to separate the two constitutional isomers 8 and 9 by gravity column chromatography failed due to their almost identical elution behaviour. However, ${ }^{1} \mathrm{H}$ NMR spectroscopy of the mixture allowed us to determine the ratio of the isomers in the crude reaction mixture. As expected, the symmetrical compound 8 was the minor component and the ratio observed, 8:9 $1: 3$, suggested a random attack of the electrophile at each of the benzene rings even in the second and third step of the threefold nitration. This corresponds to comparable findings with multiple electrophilic substitutions of the centropolyindanes and reflects the lack of electronic interaction between the aromatic units [22].

Because of the prototypical character of three-fold nitration of a TBTQ derivative, the ability to distinguish between the $C_{3}$ - and the $C_{1}$-symmetrical isomers $\mathbf{8}$ and $\mathbf{9}$ and to assess the relative amounts is addressed here in some detail (Figure 2). Notwithstanding the fact that the ${ }^{1} \mathrm{H}$ NMR spectra of compounds $\mathbf{8}$ and 9 are very similar, their isomer ratio can be determined from the mixture by assuming incremental deshielding effects caused by the nitro group placed at the benzene ring which is adjacent to that bearing the proton under observation. Thus, besides the strong deshielding effect due to the ortho- $\mathrm{NO}_{2}$ groups of the very same benzene ring, the "distal" or "proximal" nitro group at the closest neighbouring ring affects the chemical shift. For example, the resonance of the ("isolated") ortho-proton 1-H of 


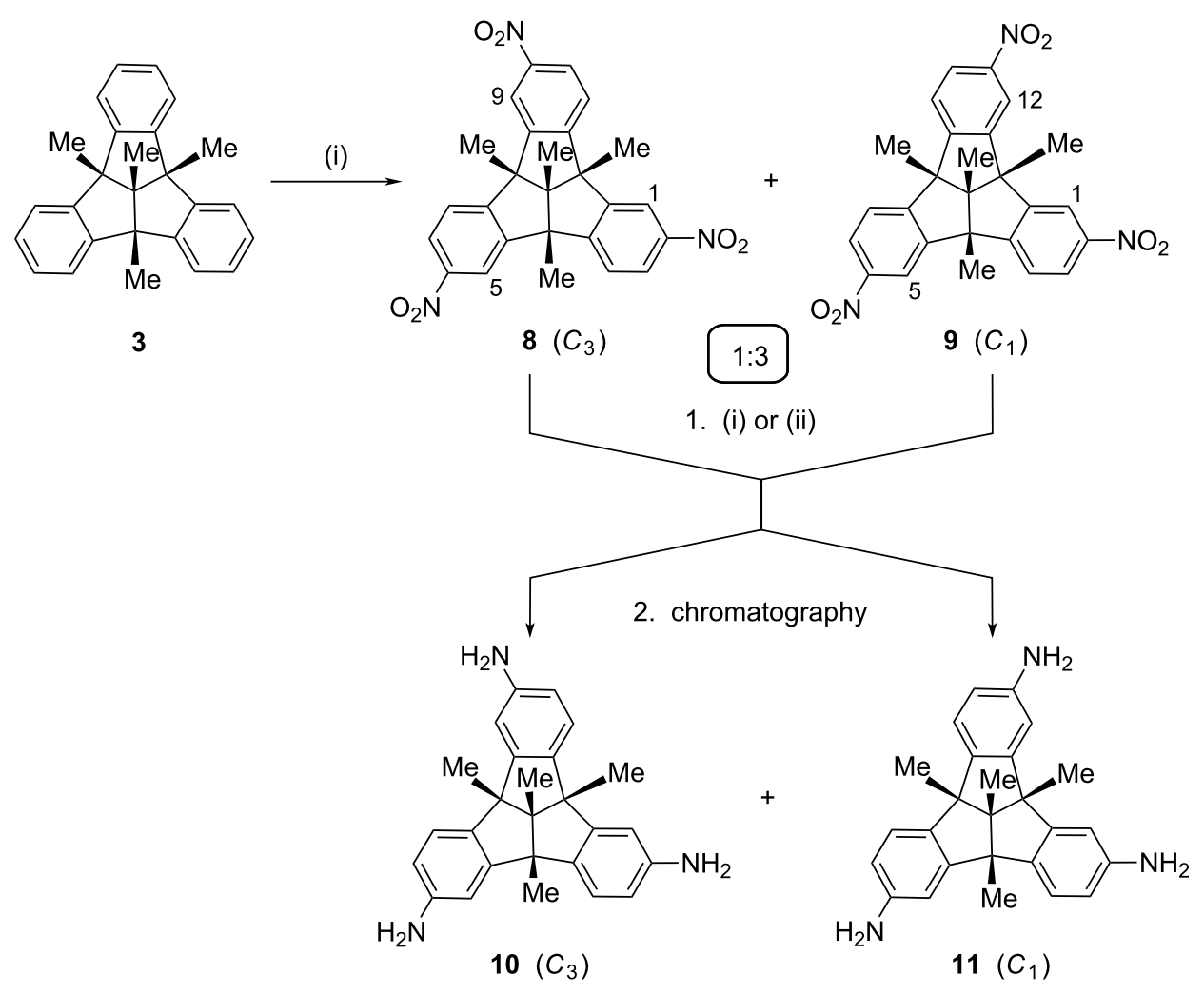

Scheme 1: Nitration of tetramethyl-TBTQ 3 to give a 1:3 mixture of the trinitro derivatives $\mathbf{8}$ and $\mathbf{9}$, and subsequent reduction of the mixture, yielding the TBTQ triamines 10 and 11. Reagents, conditions and yields: (i) $\mathrm{NaNO}_{3}, \mathrm{TFA}, 25{ }^{\circ} \mathrm{C}, 48 \mathrm{~h}$, quantitative. (ii) $\mathrm{N}_{2} \mathrm{H}_{4} \cdot \mathrm{H}_{2} \mathrm{O}(96 \%), \mathrm{FeCl} 3 \cdot 6 \mathrm{H}_{2} \mathrm{O}$, charcoal, $80{ }^{\circ} \mathrm{C}, 24 \mathrm{~h}, 81 \%$. Alternatively: (ii) $\mathrm{H}_{2}, \mathrm{Pd} / \mathrm{C}$, EtOH, 5 bar, $20{ }^{\circ} \mathrm{C}, 24 \mathrm{~h}, 91 \%$; yields after chromatography $20 \%(10)$ and $70 \%(11)$.

isomer $8\left(\mathrm{H}^{a}, \delta 8.19\right)$ is also affected to a minor extent by the distal $10-\mathrm{NO}_{2}$ group. The equivalent protons $5-\mathrm{H}^{a}$ and $9-\mathrm{H}^{a}$ of 8 suffer the same extra chemical shift but, interestingly, the isolated proton $5-\mathrm{H}^{a}$ of isomer 9 is also isochronous and contributes to the doublet $\left({ }^{4} J=2.0 \mathrm{~Hz}\right)$ at $\delta 8.19$. By contrast, the remaining isolated ortho-protons, $1-\mathrm{H}$ and 12-H, of isomer 9 resonate at slightly lower field $\left(\mathrm{H}^{a}, \delta 8.24\right)$ due to the stronger deshielding effect of the proximal $11-\mathrm{NO}_{2}$ and $2-\mathrm{NO}_{2}$ groups, respectively. Correspondingly, this significant difference in the chemical shifts $(\Delta \delta=0.05 \mathrm{ppm})$ of protons $\mathrm{H}^{a}$ and $\mathrm{H}^{a}$ of isomers 8 and 9 is found to occur inversely with the resonances of the non-isolated ortho-protons $\mathrm{H}^{c}$ and $\mathrm{H}^{c}$, and appear as doublets $\left({ }^{3} J=8.5 \mathrm{~Hz}\right)$ at $\delta 7.57$ and $\delta 7.50$, respectively. Thus, the former resonance is assigned to the equivalent protons $4-\mathrm{H}^{c}$, $9-\mathrm{H}^{c}$ and $12-\mathrm{H}^{c}$ of 8 and the isochronous proton $4-\mathrm{H}^{c}$ of $\mathbf{9}$, all having one proximal nitro group at the adjacent benzene ring. The latter resonance assigned to the isochronous protons $8-\mathrm{H}^{c^{\prime}}$ and $9-\mathrm{H}^{c^{\prime}}$ is slightly upfield-shifted $(\Delta \delta=0.07 \mathrm{ppm})$ due to the weaker deshielding effect of the respective distal $11-\mathrm{NO}_{2}$ and 6- $\mathrm{NO}_{2}$ groups. Similar arguments hold true for the meta-protons $\mathrm{H}^{b}$ and $\mathrm{H}^{b}$ of the TBTQ skeleton, with a noticeably slight perturbation in the case of $\mathrm{H}^{b}$ due to the asymmetry of 9 . In fact, the unity integral ratios observed for the six different resonances $a$ and $a^{\prime}, b$ and $b^{\prime}$, and $c$ and $c^{\prime}$ are in excellent agreement with the assumed isomer ratio 8:9 $=25: 75$ : With this ratio, the integrals of the groups of isochronous protons, e.g., $\mathrm{H}^{a}$ in $\mathbf{8}$ and 9 and $\mathrm{H}^{a}$ in 9, become equal: $\left[\mathrm{H}^{a}\right]=0.25 \times 3+0.75 \times 1=$ $\left[\mathrm{H}^{a^{\prime}}\right]=0.75 \times 2=1.50$. Finally, it may be noted that, accordingly, the 1:3 mixture of the trinitro compounds 8 and $\mathbf{9}$ is also reflected by three ${ }^{13} \mathrm{C}$ NMR lines at $\delta 25.54,25.46$ and 25.40 in the intensity ratio of ca. 3:6:3.

Reduction of the mixture of the trinitro compounds 8 and 9 was in the first instance achieved by use of hydrazine with iron(III) chloride and charcoal in refluxing methanol (Scheme 1) [23], and afforded a mixture of the triamino-TBTQs $\mathbf{1 0}$ and $\mathbf{1 1}$ in good yield (81\%). However, catalytic hydrogenolysis of compounds 8 and 9 at ambient temperature under medium pressure [20,24,25] proved to be even more efficient and gave the TBTQ-trianilines $\mathbf{1 0}$ and $\mathbf{1 1}$ in an even higher yield (91\%). At variance from the trinitrotribenzotriquinacenes, these derivatives were found to display quite different elution behaviour on silica gel. By use of ethyl acetate as an eluent, the retention factors of $\mathbf{1 0}$ and $\mathbf{1 1}$ were found to be 0.44 and 0.27 . After sep- 


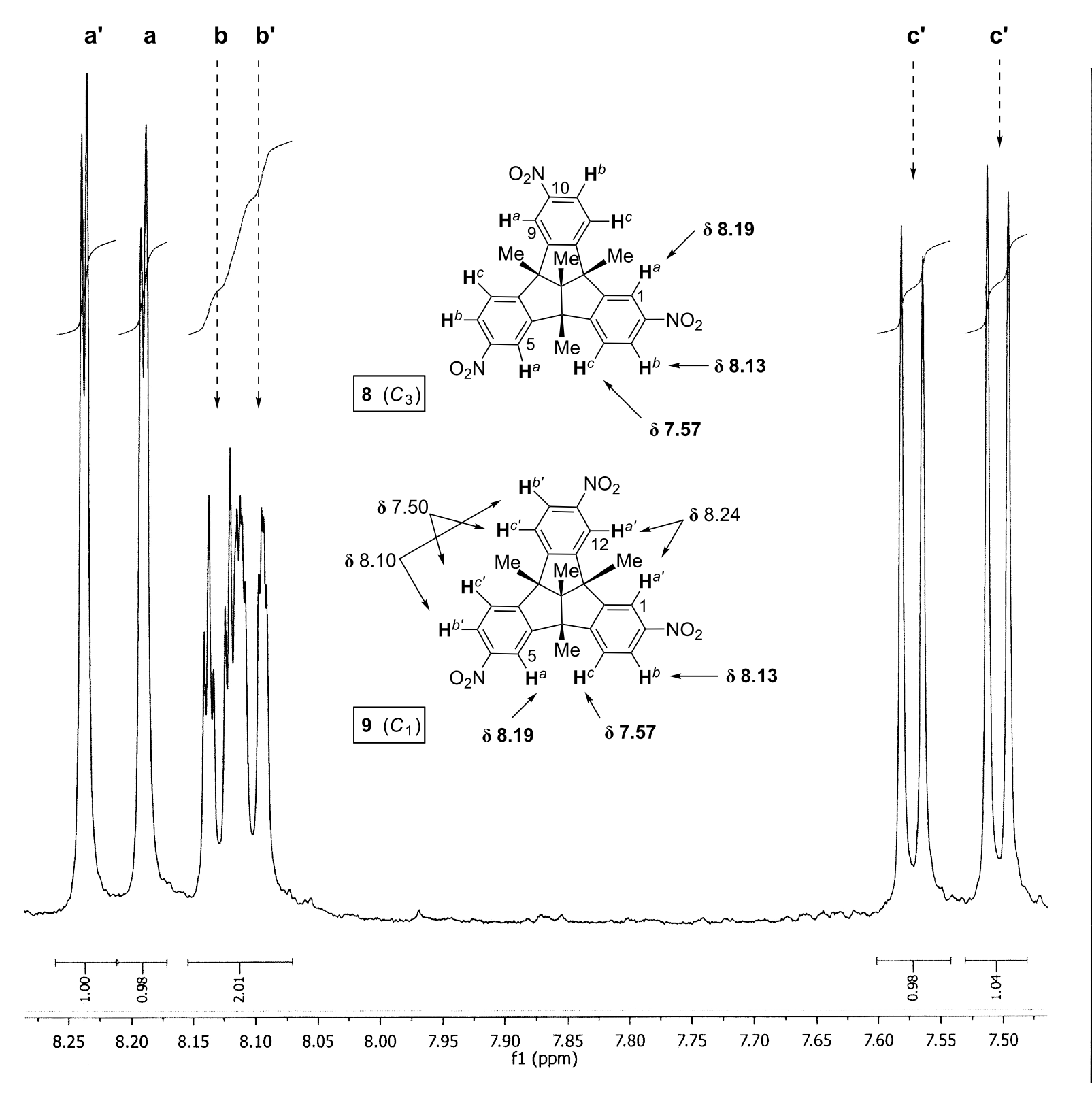

Figure 2: Partial ${ }^{1} \mathrm{H}$ NMR spectrum $\left(500 \mathrm{MHz}, \mathrm{CDCl}_{3}\right)$ of the mixture of the trinitro-TBTQ isomers 8 and 9.

aration by column chromatography, the first-eluting, $C_{3}$-symmetrical isomer $\mathbf{1 0}$ was obtained in $20 \%$ and the secondeluting, $C_{1}$-symmetrical isomer 11 in $70 \%$ yields, in line with the isomer ratio deduced for the trinitro precursors.

Similar to the trinitro compounds $\mathbf{8}$ and $\mathbf{9}$, the triamines $\mathbf{1 0}$ and 11 were found to give apparently identical EI mass spectra. In all of these cases, loss of a methyl radical is, by far, the dominating primary fragmentation process. However, ${ }^{1} \mathrm{H}$ and ${ }^{13} \mathrm{C}$ NMR spectroscopy allowed us to unequivocally assign the isomers. The $C_{3}$-symmetry of compound $\mathbf{1 0}$ is reflected by the relatively well resolved doublets at $\delta 6.47$ and 7.06 and the rela- tively sharp singlet at $\delta 6.59$, all of which having unity integral ratios. As expected, the chemical shifts in the spectrum of the $C_{1}$-symmetrical isomer $\mathbf{1 1}$ are very similar to those of $\mathbf{1 0}$ but very slight differences of the chemical shifts are evident from the significantly broadened and more complex signals. Notably, these differences are much less pronounced as was the case with the trinitro precursors; thus, the splitting of the resonances of the isolated protons $1-\mathrm{H}, 5-\mathrm{H}$ and $12-\mathrm{H}$ of isomer 11 into two singlets at $\delta 6.59(1 \mathrm{H})$ and $\delta 6.61(2 \mathrm{H})$ is minute. Moreover, and quite specifically, the proton-decoupled ${ }^{13} \mathrm{C}$ NMR spectrum of the $C_{3}$-symmetrical isomer $\mathbf{1 0}$ exhibits a single line at $\delta 61.7$ due to the three benzhydrylic bridgeheads and another line 
at $\delta 25.9$ due to the three methyl groups attached to these positions, whereas the spectrum of $\mathbf{1 1}$ shows two sets of three lines at $\delta 61.1,61.7$ and 62.2 and at $\delta 25.7,25.9$ and 26.1, respectively.

The triamino-substituted TBTQs $\mathbf{1 0}$ and $\mathbf{1 1}$ readily added three equivalents of phenylisocyanate to give the corresponding $C_{3}$ and $C_{1}$-symmetrical TBTQ-based tris-ureas 5 and $\mathbf{6}$ in very good yields (Scheme 2). These conversions were as efficient as the corresponding reactions of the tetraaminocalix[4]arenes [10]. As expected, the colorless amorphous solids had good solubility in polar solvents but not in non-polar ones. Whereas EI and DEI mass spectrometry failed, ionization by $\mathrm{FAB}(+)$ furnished almost identical mass spectra that clearly showed the expected $[\mathrm{M}+\mathrm{H}]^{+}$peaks at $m / z 739$ along with very minor signals for the twofold condensation product. However, the ${ }^{1} \mathrm{H}$ NMR spectra of compounds $\mathbf{5}$ and $\mathbf{6}$ gave no hint to such impurities.

In analogy to the triamino precursors $\mathbf{1 0}$ and 11, the TBTQ-trisureas 5 and $\mathbf{6}$ gave very similar ${ }^{1} \mathrm{H}$ NMR spectra even at $600 \mathrm{MHz}$ but, again, the spectrum of the non-symmetrical 6 isomer revealed significant splitting of the peaks. The spectrum of the $C_{3}$-symmetrical 5 isomer exhibited two characteristic singlets at $\delta 8.54$ and $\delta 8.60$ for the two sets of amido protons. ${ }^{1} \mathrm{H},{ }^{1} \mathrm{H}-\mathrm{COSY}$ measurements allowed us to assign these resonances to the "outer" ( $\mathrm{Ph}-\mathrm{NHCO})$ and the "inner" (TBTQ-NHCO) amido protons, respectively, of the three equivalent urea groups. In fact, the singlet for the adjacent protons, $1-\mathrm{H}, 5-\mathrm{H}$ and $9-\mathrm{H}(\delta 7.55)$, at the TBTQ nucleus, as well as the doublet for the six ortho-protons of the phenyl groups $(\delta 7.43)$, were found to be useful for this assignment. The three equivalent bridgehead methyl groups of 5 resonate at $\delta 1.57$ and those of the central methyl group appear at $\delta 1.30$.

Although the bridgehead chemistry of the tribenzotriquinacenes has been extensively investigated [1-4,7], the attachment of multifunctional groupings at the convex surface of the TBTQ skeleton has been only scarcely examined [4]. Therefore, we subjected the previously described bridgehead triaminotribenzotriquinacene 12 [4] to the reaction with phenylisocyanate in analogy to the conversion of the peripheral triamines $\mathbf{1 0}$ and 11, and isolated the corresponding $C_{3 v}$-symmetrical TBTQ trisurea 7 in very good yield (Scheme 2). Again, characterization by $\mathrm{FAB}(+)$ and also by $\mathrm{ESI}(+)$ mass spectrometry was straightforward; intense $[\mathrm{M}+\mathrm{H}]^{+}(m / z$ 697) and, respectively,

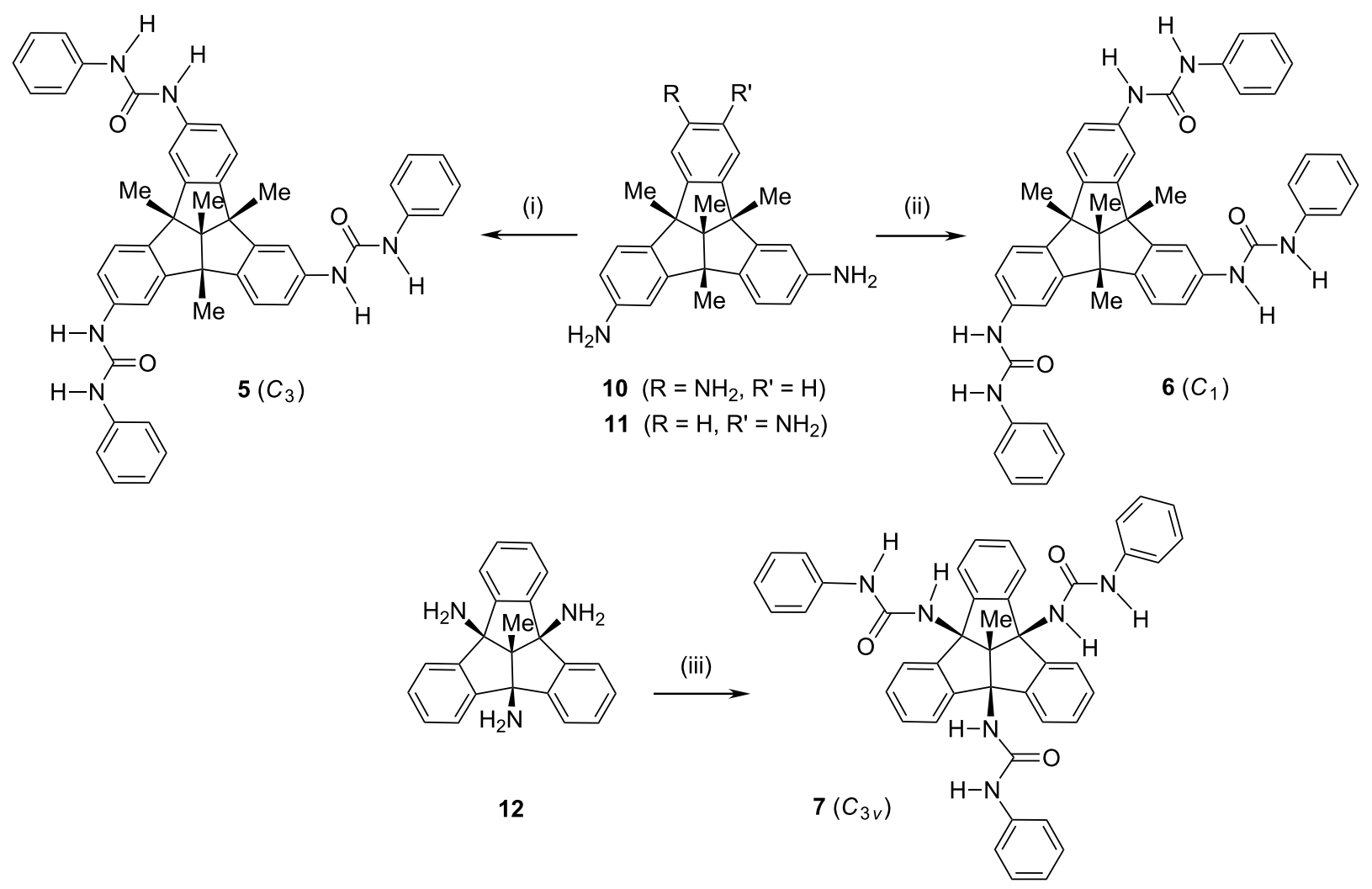

Scheme 2: Syntheses of tris-phenylurea-substituted tribenzotriquinacenes 5-7. Reagents and conditions: (i) $\mathrm{PhNCO} \mathrm{CHCl}_{3}, 50{ }^{\circ} \mathrm{C}, 6 \mathrm{~h}, 84 \%$. (ii) ditto, $86 \%$. (iii) ditto, $96 \%$. 
$[\mathrm{M}+\mathrm{Na}]^{+}(\mathrm{m} / \mathrm{z} 719)$ peaks were in accord with the product of threefold addition. Interestingly, the ${ }^{1} \mathrm{H}$ NMR spectra of compound 7 showed pronounced solvent effects on the NH proton resonances. The outer protons were found to resonate at $\delta 8.86$ in DMSO- $d_{6}$ but at $\delta 6.80$ in $\mathrm{C}_{2} \mathrm{D}_{2} \mathrm{Cl}_{4}$, and the inner protons to resonate at $\delta 6.57$ in DMSO- $d_{6}$ and at $\delta 5.37$ in $\mathrm{C}_{2} \mathrm{D}_{2} \mathrm{Cl}_{4}$. Thus, the change from the polar to the low-polarity solvent gives rise to a high-field shifts of $\Delta \delta=2.3$ and $1.4 \mathrm{ppm}$, respectively. This effect was attributed to the preferred formation of hydrogen-bound dimers of the tris-urea 7 in tetrachloroethane solution.

As outlined above, the potential dimerization of the threefold urea-functionalized TBTQ derivatives 5, 6 and 7 was one motif for this work. In fact, some evidence for the formation of neutral dimers in low-polarity solvents was found. As mentioned above, the strong high-field shift observed in dichloroethane solution for the NH protons of the bridgehead TBTQ tris-urea 7 suggests the formation of a dimeric aggregate. Specifically, the particularly strong shielding of the external NH protons $(\Delta \delta=-2.3)$ may point to the formation of face-to-face dimers in which the arene units of the opposite TBTQ core exert pronounced magnetic anisotropy effects.

In the case of the peripheral TBTQ tris-ureas 5 and $\mathbf{6},{ }^{1} \mathrm{H}$ NMR measurements in DMSO and tetrachloroethane revealed a surprising effect which may also be attributed to aggregation of these molecules in low-polarity solvents. Both of these compounds were found to be only poorly soluble in $\mathrm{C}_{2} \mathrm{D}_{2} \mathrm{Cl}_{4}$ and their ${ }^{1} \mathrm{H}$ NMR spectra in this solvent showed very broad signals for the NH protons. Therefore, assignment of NH and arene proton resonances was impossible even at elevated temperatures $\left(\leq 120^{\circ} \mathrm{C}\right)$. Nevertheless, the ${ }^{1} \mathrm{H}$ resonances of the three benzhydrylic and the single central methyl groups were clearly detectable in both DMSO- $d_{6}$ and $\mathrm{C}_{2} \mathrm{D}_{2} \mathrm{Cl}_{4}$. However, in the latter solvent, the protons of the benzhydrylic methyl groups of 5 and $\mathbf{6}$ were found to resonate at significantly higher fields than those of the central methyl group (Table 1). This is in stark contrast to the relative chemical shifts found with DMSO- $d_{6}$ as a solvent and with all TBTQ derivatives studied so far.

\begin{tabular}{|c|c|c|c|}
\hline \multirow[t]{2}{*}{ Compound } & \multirow{2}{*}{$\begin{array}{l}\text { Bridgehead methyl } \\
\text { groups }\end{array}$} & \multicolumn{2}{|c|}{ Solvent } \\
\hline & & DMSO- $d_{6}$ & $\mathrm{C}_{2} \mathrm{D}_{2} \mathrm{Cl}_{4}$ \\
\hline \multirow[t]{2}{*}{5} & $12 \mathrm{~d}-\mathrm{CH}_{3}$ & 1.30 & 1.34 \\
\hline & $4 b-, 8 b-, 12 b-\mathrm{CH}_{3}$ & 1.57 & 1.17 \\
\hline \multirow[t]{2}{*}{6} & $12 \mathrm{~d}-\mathrm{CH}_{3}$ & 1.30 & 1.26 \\
\hline & $4 b-, 8 b-, 12 b-C_{3}$ & 1.56 & 1.07 \\
\hline
\end{tabular}

It is noteworthy that the ${ }^{1} \mathrm{H}$ resonance of the central methyl group is hardly affected by the solvent, whereas the resonance of the outer bridgehead methyl groups is shifted to a higher field by $\Delta \delta \approx 0.4 \mathrm{ppm}$ for the $C_{3}$-symmetrical compound $\mathbf{5}$ and by even $\Delta \delta \approx 0.5 \mathrm{ppm}$ for the $C_{1}$-symmetrical compound $\mathbf{5}$. Similar to the argument mentioned above for compound 7 , this effect could be attributed to the shielding effect exerted by the arene units of the TBTQ core belonging to the opposite molecule associated in face-to-face dimers of either $\mathbf{5}$ or $\mathbf{6}$. Notably, however, and in contrast to the case of compound 7, the TBTQ molecules in such dimers would be aggregated with their concave sides toward each other.

Finally, it should be noted that all of the $\mathrm{FAB}(+)$ and $\operatorname{ESI}(+)$ mass spectra recorded with compounds 5, 6 and 7 exhibited strong signals for dimeric quasi-molecular ions. For example, the ESI(+) mass spectrum of the $C_{1}$-symmetrical isomer 6 obtained from pure methanol solution exhibited the ions $[\mathrm{M}+\mathrm{Na}]^{+}\left(m / z\right.$ 761) and $[2 \mathrm{M}+\mathrm{Na}]^{+}(\mathrm{m} / z$ 1499) in the abundance ratio of ca. 100:20. About the same ratio was found when a chloroform/methanol mixture (99:1) was used. By contrast, the $C_{3}$-symmetrical isomer $\mathbf{5}$ sprayed from the latter solvent gave $\operatorname{ESI}(+)$ mass spectra that reproducibly show abundant peaks for (singly charged) $[\mathrm{M}+2 \mathrm{Na}]^{+}(\mathrm{m} / z$ 784) and $[2 \mathrm{M}+$ $2 \mathrm{Na}]^{+}$ions. This difference may be due to the different molecular symmetry. The $\mathrm{FAB}(+)$ mass spectrum of the bridgehead tris-urea 7 (obtained with NBA as a matrix) and the corresponding $\mathrm{ESI}(+)$ mass spectrum obtained from pure methanol exhibited the $[\mathrm{M}+\mathrm{H}]^{+}\left(\mathrm{m} / z\right.$ 697) and the $[\mathrm{M}+\mathrm{Na}]^{+}(\mathrm{m} / z$ 719) peaks, respectively, but only very minor dimeric quasi-molecular ion peaks.

No more detailed analysis of the dimerization of the new TBTQ-based tris-urea 5, 6, and $\mathbf{7}$ has been carried out so far. Also, it remains open whether homo- or heterochiral association is preferred with the peripheral tris-urea $\mathbf{5}$ and $\mathbf{6}$ and whether the $C_{3}$-symmetrical isomer 5 behaves differently from the $C_{1}$-symmetrical isomer $\mathbf{6}$. Nevertheless, the observations reported in the present work point to the existence of TBTQ tris-urea dimers in non-polar solvents. Congeners bearing three longer-chain aliphatic groups in place of the phenylcarbamoyl residues appear to be good candidates for further studies in this field.

\section{Experimental}

2,6,10-Trinitro-4b,8b,12b,12d-tetramethyl-4b,8b,12b,12dtetrahydrodibenzo-[2,3:4,5]pentaleno[1,6-ab]indene $(8)$ and 2,6,11-trinitro-4b,8b,12b,12d-tetramethyl-4b,8b,12b,12dtetrahydrodibenzo $[2,3: 4,5]$-pentaleno-[1,6-ab]indene (9) (mixture of isomers). A suspension of tetramethyltribenzotriquinacene $3(250 \mathrm{mg}, 743 \mathrm{mmol})$ in trifluoroacetic acid 
(40 mL) was stirred while sodium nitrate $(756 \mathrm{mg}, 8.92 \mathrm{mmol})$ was added in small portions. The reaction mixture became a yellow solution after several hours and stirring was continued for a total of $48 \mathrm{~h}$ at ambient temperature. After the addition of water $(25 \mathrm{~mL})$, the mixture was cooled with ice and the $\mathrm{pH}$ adjusted to $\approx 10$ by the careful addition of sodium hydroxide (solid or $6 \mathrm{M}$ aqueous solution). Repeated extraction with chloroform, drying of the combined extracts with sodium sulfate and removal of the solvent under reduced pressure followed by column chromatography (silica gel $/ \mathrm{CHCl}_{3}$ ) gave a mixture of the trinitro compounds 8 and $9(350 \mathrm{mg}, 100 \%)$ in a ratio of ca. $1: 3$ as a yellow, amorphous solid; $R_{\mathrm{f}}\left(\mathrm{CHCl}_{3}\right) 0.74 ; \mathrm{mp}$ $>360{ }^{\circ} \mathrm{C}$; IR (KBr): $v=3073,2974,2934,1594,1530,1475$, 1453, 1396, 1345, 1207, 1153, 1112, 1097, 1067, 1032, 907, $887,825,742,674 \mathrm{~cm}^{-1} ;{ }^{1} \mathrm{H} \mathrm{NMR}\left(500 \mathrm{MHz}, \mathrm{CDCl}_{3}\right)$, integral data given as parts of a total of $9 \mathrm{H}^{a r}$ and $12 \mathrm{H}^{m e}: \delta=8.240(\mathrm{~d}$, $\left.J=2.1 \mathrm{~Hz}, 1.5 \mathrm{H}^{a r}\right), 8.193\left(\mathrm{~d}, J=2.1 \mathrm{~Hz}, 1.5 \mathrm{H}^{a r}\right), 8.125(\mathrm{~d}$, $J \approx 8.5 \mathrm{~Hz}$, with fine splitting of $J \approx 1.9 \mathrm{~Hz}, 1.5 \mathrm{H}^{a r}$ ), 8.105 (br $\left.\mathrm{d}, J \approx 8.5 \mathrm{~Hz}, 1.5 \mathrm{H}^{a r}\right), 7.575\left(\mathrm{~d}, J=8.5 \mathrm{~Hz}, 1.5 \mathrm{H}^{a r}\right), 7.506(\mathrm{~d}$, $\left.J=8.5 \mathrm{~Hz}, 1.5 \mathrm{H}^{a r}\right), 1.77\left(\mathrm{~s}, 2.25 \mathrm{H}^{m e}\right), 1.75\left(\mathrm{~s}, 4.5 \mathrm{H}^{m e}\right), 1.73$ (s, $\left.2.25 \mathrm{H}^{m e}\right), 1.43\left(\mathrm{~s}, 3 \mathrm{H}^{m e}\right) ;{ }^{13} \mathrm{C} \mathrm{NMR}$ (75 MHz, acetone- $\left.d_{6}\right)$ : $\delta=155.9,155.6,150.8,150.7,149.9$ (all C), 125.6, 124.8, 124.7, 119.7 (all CH), 72.3, 64.1, 63.94, 63.86 (all C), 25.54, 25.46, 25.4, $16.1\left(\right.$ all $\left.\mathrm{CH}_{3}\right)$; MS (EI, $\left.70 \mathrm{eV}\right) \mathrm{m} / z$ (\%): 471 (9) $\left[\mathrm{M}^{+\bullet}\right], 456(100), 410$ (9), 395 (7); accurate mass (EI, $\left.70 \mathrm{eV}\right)$ : $m / z 456\left(\left[\mathrm{M}-\mathrm{CH}_{3}\right]^{+}\right), \mathrm{C}_{25} \mathrm{H}_{18} \mathrm{~N}_{3} \mathrm{O}_{6}$, calcd 456.1196; found 456.1196 .

2,6,10-Triamino-4b,8b,12b,12d-tetramethyl-4b,8b,12b,12dtetrahydrodibenzo- $[2,3: 4,5]$ pentaleno $[1,6-a b]$ indene (10) and 2,6,11-triamino-4b,8b,12b,12d-tetramethyl$4 \mathrm{~b}, 8 \mathrm{~b}, 12 \mathrm{~b}, 12 \mathrm{~d}$-tetrahydrodibenzo $[2,3: 4,5]$ pentaleno $[1,6-$ $a b$ ]indene (11). Procedure A. A suspension containing the mixture of isomeric trinitrotribenzotriquinacenes $\mathbf{8}$ and $\mathbf{9}$ described above (230 mg, $488 \mathrm{mmol}$ ), charcoal (32 mg) and iron(III) chloride hexahydrate $(10 \mathrm{mg})$ in methanol $(10 \mathrm{~mL})$ was heated to reflux for $15 \mathrm{~min}$ and then hydrazine hydrate $(97 \%, 120 \mathrm{mg})$ added. After heating for $4 \mathrm{~h}$ further $\mathrm{FeCl}_{3} \cdot 6 \mathrm{H}_{2} \mathrm{O}(10 \mathrm{mg})$ and $120 \mathrm{mg} \mathrm{N} \mathrm{H}_{4} \cdot \mathrm{H}_{2} \mathrm{O}(120 \mathrm{mg})$ were added. The mixture was heated under reflux for a total of $24 \mathrm{~h}$, allowed to cool and filtered through silica with ethyl acetate. Removal of the solvent gave a mixture of the triamines $\mathbf{1 0}$ and $\mathbf{1 1}(151 \mathrm{mg}, 81 \%)$ as a yellow solid, the components of which can be separated by chromatography. Procedure B. The mixture of isomers 8 and 9 described above (500 mg, $1.06 \mathrm{mmol})$ and $\mathrm{Pd} / \mathrm{C}(10 \%, 100 \mathrm{mg})$ were suspended in ethanol $(100 \mathrm{~mL})$ and shaken under a hydrogen atmosphere at 5 bar at ambient temperature for $24 \mathrm{~h}$. The catalyst was removed by filtration through silica gel and the solvent removed under reduced pressure. The triamines $\mathbf{1 0}$ and 11 were separated by column chromatography (silica gel, EtOAc) to yield the $C_{3}$-symmetrical isomer $\mathbf{1 0}(115 \mathrm{mg}, 20 \%)$ and the $C_{1}$-symmetrical isomer $11(399 \mathrm{mg}, 70 \%)$. Isomer 10: $R_{\mathrm{f}}$ (EtOAc) $0.44 ; \mathrm{mp} 344^{\circ} \mathrm{C}$; IR $(\mathrm{KBr}): v=3445,3372,3208$, 3013, 2960, 2927, 2866, 1619, 1494, 1449, 1434, 1389, 1370, 1313, 1276, 1258, 1238, 1188, 1157, 1137, 1078, 1028, 926, $857,815,756,708,613 \mathrm{~cm}^{-1} ;{ }^{1} \mathrm{H}$ NMR $\left(500 \mathrm{MHz}, \mathrm{CDCl}_{3}\right): \delta=$ 7.06 (d, $J=8.0 \mathrm{~Hz}, 3 \mathrm{H}), 6.59$ (s, 3H), 6.47 (d, $J=7.4 \mathrm{~Hz}, 3 \mathrm{H})$, 3.45 (br s, 6H), 1.53 (s, 9H), 1.27 (s, 3H); ${ }^{13} \mathrm{C}$ NMR $(125 \mathrm{MHz}$, $\left.\mathrm{CDCl}_{3}\right): \delta=150.7,145.9,139.2($ all C), 123.3, 115.1, 109.1 (all $\mathrm{CH}), 70.6(\mathrm{C}), 61.7(\mathrm{C}), 25.9\left(\mathrm{CH}_{3}\right), 16.1\left(\mathrm{CH}_{3}\right)$; MS (EI, $70 \mathrm{eV}) \mathrm{m} / \mathrm{z}(\%): 381(26)\left[\mathrm{M}^{+\bullet}\right], 366$ (100), 351 (5), 336 (9), 319 (5); accurate mass (EI, $70 \mathrm{eV}): \mathrm{C}_{26} \mathrm{H}_{27} \mathrm{~N}_{3}\left(\mathrm{M}^{+\bullet}\right)$, calcd 381.2205, found 381.2206. Isomer 11: $R_{\mathrm{f}}$ (EtOAc) 0.27; $\mathrm{mp} 339^{\circ} \mathrm{C}$; IR (KBr): $v=3454,3374,3216,3014,2961,2929$, 2864, 1618, 1490, 1453, 1434, 1392, 1371, 1311, 1266, 1245, $1183,1156,1133,1077,1027,931,860,814,753 \mathrm{~cm}^{-1}$; ${ }^{1} \mathrm{H}$ NMR (500 MHz, $\left.\mathrm{CDCl}_{3}\right): \delta=7.09-7.03(\mathrm{~m}, 3 \mathrm{H}), 6.61(\mathrm{~s}$, $2 \mathrm{H}), 6.59(\mathrm{~s}, 1 \mathrm{H}), 6.49-6.42(\mathrm{~m}, 3 \mathrm{H}), 3.41(\mathrm{br} \mathrm{s}, 6 \mathrm{H}), 1.53(\mathrm{~s}$, 9H), $1.27(\mathrm{~s}, 3 \mathrm{H}) ;{ }^{13} \mathrm{C}$ NMR $\left(125 \mathrm{MHz}, \mathrm{CDCl}_{3}\right): \delta=150.3$, 150.0, 149.6, 145.8, 145.7, 145.6, 140.3, 139.9, 139.6 (all C), $123.4,123.22,123.19,115.4,115.3,115.2,109.3,109.1$ (all $\mathrm{CH}$ ), 70.6, 62.2, 61.7, 61.1 (all C), 26.1, 25.9, 25.7, 16.1 (all

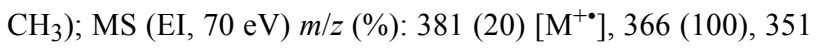
(4), 336 (8), 319 (4); accurate mass (EI, $70 \mathrm{eV}$ ): $\mathrm{C}_{26} \mathrm{H}_{27} \mathrm{~N}_{3}$ $\left(\mathrm{M}^{+\bullet}\right)$, calcd 381.2205, found 381.2204.

2,6,10-Tris $[(N$-phenylcarbamoyl)amino $]-4 b, 8 b, 12 b, 12 d-t e-$ trameth y l- 4 b, 8 b, 12 b, 12 d-t e trah ydrodibenzo$[2,3: 4,5]$ pentaleno[1,6-ab]indene (5). A solution of the triamino-TBTQ $10(115 \mathrm{mg}, 302 \mu \mathrm{mol})$ in anhydrous chloroform $(70 \mathrm{~mL})$ was stirred under an argon atmosphere while phenylisocyanate $(108 \mu \mathrm{L}, 995 \mu \mathrm{mol})$ was added. The mixture was heated at $50{ }^{\circ} \mathrm{C}$ for $6 \mathrm{~h}$ and the solvent was removed under reduced pressure. The colorless solid residue was suspended in $n$-hexane, filtered by suction and dried in vacuo to give the trisurea 5 (187 $\mathrm{mg}, 84 \%)$ as a colorless amorphous solid, $\mathrm{mp}$ $>360{ }^{\circ} \mathrm{C}$; IR (KBr): $v=3372,2968,2928,1663,1598,1546$, 1491, 1443, 1416, 1372, 1311, 1227, 1080, 752, $692 \mathrm{~cm}^{-1}$; ${ }^{1} \mathrm{H}$ NMR (500 MHz, DMSO- $d_{6}$ ), see Supporting Information File 1 for $600 \mathrm{MHz}$ spectrum: $\delta=8.60(\mathrm{~s}, 3 \mathrm{H}), 8.54(\mathrm{~s}, 3 \mathrm{H})$, $7.55(\mathrm{~d}, J=1.4 \mathrm{~Hz}, 3 \mathrm{H}), 7.43(\mathrm{~d}, J=8.0 \mathrm{~Hz}, 6 \mathrm{H}), 7.26(\mathrm{t}, J=$ $7.9 \mathrm{~Hz}, 9 \mathrm{H}), 7.18\left(\mathrm{dd},{ }^{3} J=8.4 \mathrm{~Hz},{ }^{4} J=1.4 \mathrm{~Hz}, 3 \mathrm{H}\right), 6.94(\mathrm{t}, J=$ $7.4 \mathrm{~Hz}, 3 \mathrm{H}), 1.57$ (s, 9H), 1.30 (s, 3H); ${ }^{13} \mathrm{C} \mathrm{NMR} \mathrm{(125} \mathrm{MHz,}$ DMSO-d 6 ): $\delta=152.6,149.5,142.1,139.8,139.1$ (all C), 128.8, 122.8, 121.8, 118.2, 112.6 (all CH), 69.9 (C), 61.7 (C), 25.5 $\left(\mathrm{CH}_{3}\right)$. The $12 \mathrm{~d}-\mathrm{CH}_{3}$ group does not show a separate resonance. ${ }^{1} \mathrm{H}$ NMR (500 MHz, $\left.\mathrm{C}_{2} \mathrm{D}_{2} \mathrm{Cl}_{4}\right): \delta=7.30-6.90(\mathrm{~m}, 30 \mathrm{H}), 1.34$ (s, 3H), 1.17 (s, 9H); MS (FAB(+), NBA) $m / z(\%): 1479$ (1) $[2 \mathrm{M}+\mathrm{H}]^{+}, 739(97)[\mathrm{M}+\mathrm{H}]^{+}, 723(19) ; \mathrm{MS}[\mathrm{ESI}(+), \mathrm{MeOH}]$ $m / z(\%): 1499.8(8)[2 \mathrm{M}+\mathrm{Na}]^{+}, 1358.7$ (6), 761.3 (100) $[\mathrm{M}+\mathrm{Na}]^{+}, 756.4$ (19), 739.3 (12), 642.3 (25), 620.3 (28); MS $\left[\operatorname{ESI}(+), \mathrm{CHCl}_{3}\right.$ and $\left.\sim 1 \% \mathrm{MeOH}\right] \mathrm{m} / z(\%): 1565.8(1), 1523.8$ 
(7) $[2 \mathrm{M}+2 \mathrm{Na}]^{+}, 1500.8(1), 1403.8$ (1), $1358.7(1), 826.4$ (25), $784.4(100)[\mathrm{M}+2 \mathrm{Na}]^{+}, 757.4$ (19), 665.4 (68); MS [ESI(+), $\left.\mathrm{MeOH},\left(\mathrm{CH}_{3}\right)_{4} \mathrm{NPF}_{6}\right] \mathrm{m} / z(\%): 1551.9$ (2) [2 $\mathrm{M}+$ $\left.\left(\mathrm{CH}_{3}\right)_{4} \mathrm{~N}\right]^{+}, 812.5(100)\left[\mathrm{M}+\left(\mathrm{CH}_{3}\right)_{4} \mathrm{~N}\right]^{+}, 761.3(46), 680.1$ (52), 620.3 (12); combustional analysis: $\mathrm{C}_{47} \mathrm{H}_{42} \mathrm{~N}_{6} \mathrm{O}_{3} \cdot \mathrm{H}_{2} \mathrm{O}$ calcd C 74.58, H 5.86, N 11.10, found C 74.57, H 6.09, N 10.98.

2,6,11-Tris [ $(N$-phenylcarbamoyl)amino]-4b,8b,12b,12dtetrameth y $1-4 b, 8 b, 12$ b, 12 d-tetrahydrodibenzo$[2,3: 4,5]$ pentaleno $[1,6-a b]$ indene (6). In analogy to the procedure given above, triaminotribenzotriquinacene $11(104 \mu \mathrm{g}$, $273 \mu \mathrm{mol})$ was dissolved in anhydrous chloroform $(70 \mathrm{~mL})$ and reacted with phenylisocyanate $(98 \mu \mathrm{L}, 901 \mu \mathrm{mol})$ under argon. The mixture was heated at $50{ }^{\circ} \mathrm{C}$ for $6 \mathrm{~h}$ and then treated as above to yield the tris-urea $6(173 \mathrm{mg}, 86 \%)$ as a colorless, amorphous solid, mp $257{ }^{\circ} \mathrm{C}$ (decomp.); IR (KBr): $v=3381$, 2968, 2928, 1664, 1598, 1549, 1491, 1443, 1415, 1372, 1311, 1227, 1079, 752, $692 \mathrm{~cm}^{-1}$; ${ }^{1} \mathrm{H}$ NMR (500 MHz, DMSO- $d_{6}$ ), see Supporting Information File 1 for $600 \mathrm{MHz}$ spectrum: $\delta=$ $8.62(\mathrm{~s}, 1 \mathrm{H}), 8.60(\mathrm{~s}, 2 \mathrm{H}), 8.57(\mathrm{~s}, 1 \mathrm{H}), 8.56(\mathrm{~s}, 1 \mathrm{H}), 8.54(\mathrm{~s}$, $1 \mathrm{H}), 7.53(\mathrm{~d}, J=1.4 \mathrm{~Hz}, 1 \mathrm{H}), 7.49(\mathrm{~d}, J=1.3 \mathrm{~Hz}, 1 \mathrm{H}), 7.46$ (d, $J=1.4 \mathrm{~Hz}, 1 \mathrm{H}), 7.42(\mathrm{~d}, J=7.9 \mathrm{~Hz}, 6 \mathrm{H}), 7.38(\mathrm{~d}, J=8.4 \mathrm{~Hz}$, $1 \mathrm{H}), 7.37$ (d, $J=8.3 \mathrm{~Hz}, 1 \mathrm{H}), 7.25(\mathrm{~m}, 9 \mathrm{H}), 7.16(\mathrm{dd}, J=$ $8.3 \mathrm{~Hz}, J=1.5 \mathrm{~Hz}, 1 \mathrm{H}), 6.94(\mathrm{t}, J=7.3 \mathrm{~Hz}, 3 \mathrm{H}), 1.56(\mathrm{~s}, 9 \mathrm{H})$, $1.30(\mathrm{~s}, 3 \mathrm{H}) .{ }^{13} \mathrm{C}$ NMR $\left(125 \mathrm{MHz}, \mathrm{DMSO}-d_{6}\right): \delta=152.6$, $149.2,149.0,148.7,142.9,142.6,142.4,139.7,139.1,139.0$ (all C), 128.7, 123.1, 123.0, 122.9, 121.7, 118.4, 118.2, 112.5, 112.4, 112.3 (all CH), 69.9, 62.2, 61.7, 61.3 (all C), $25.6\left(\mathrm{CH}_{3}\right)$, $15.8\left(\mathrm{CH}_{3}\right) ;{ }^{1} \mathrm{H}$ NMR $\left(500 \mathrm{MHz}, \mathrm{C}_{2} \mathrm{D}_{2} \mathrm{Cl}_{4}\right): \delta=7.32$ (br s), 7.22 (br s), 7.20 (br s), 7.19 (br s), 7.03 (br s), 7.00 (br s), 6.91 (br s), 1.26 (br s, 3H), 1.07 (br s, 9H); MS [FAB(+), NBA] $m / z(\%): 1478$ (2) $[2 \mathrm{M}+\mathrm{H}]^{+}, 739(73)[\mathrm{M}+\mathrm{H}]^{+}, 723$ (7); MS $[\mathrm{ESI}(+), \mathrm{MeOH}] \mathrm{m} / z(\%): 1500.6(19)[2 \mathrm{M}+\mathrm{Na}]^{+}, 1136.4(4)$, $767.3(9), 761.3(100)[\mathrm{M}+\mathrm{Na}]^{+}, 756.3(28), 739.3(12), 670.3$ (6), 620.3 (7); $\mathrm{MS}\left[\operatorname{ESI}(+), \mathrm{CHCl}_{3}\right.$ and $\left.\sim 1 \% \mathrm{MeOH}\right] \mathrm{m} / z(\%)$ : $1500.7(9)[2 \mathrm{M}+\mathrm{Na}]^{+}, 761.4(100)[\mathrm{M}+\mathrm{Na}]^{+}$; $\mathrm{MS}[\operatorname{ESI}(+)$, $\left.\mathrm{MeOH},\left(\mathrm{CH}_{3}\right)_{4} \mathrm{NPF}_{6}\right] \mathrm{m} / z(\%): 1551.8(5)\left[2 \mathrm{M}+\left(\mathrm{CH}_{3}\right)_{4} \mathrm{~N}\right]^{+}$, $1499.6(5), 848.6(17), 812.4(70)\left[\mathrm{M}+\left(\mathrm{CH}_{3}\right)_{4} \mathrm{~N}\right]^{+}, 761.3(76)$, 756.3 (100), 739.3 (54), 663.4 (20), 620.3 (27), 529.4 (30); combustional analysis: $\mathrm{C}_{47} \mathrm{H}_{42} \mathrm{~N}_{6} \mathrm{O}_{3} \cdot \mathrm{H}_{2} \mathrm{O}$ calcd $\mathrm{C} 74.58$, $\mathrm{H} 5.86, \mathrm{~N} 11.10$, found $\mathrm{C} 74.51, \mathrm{H} 5.92, \mathrm{~N} 10.92$.

12d-Methyl-4b,8b,12b-tris [( $N$-phenylcarbamoyl)amino]$4 b, 8 b, 12 b, 12 d-t e t r a h y d r o d i b e n z o[2,3: 4,5]$ pentaleno $[1,6$ $a b$ ]indene (7). Similar to the procedures given above, triaminotribenzotriquinacene $\mathbf{1 2}(125 \mu \mathrm{g}, 371 \mu \mathrm{mol})$ and phenylisocyanate $(133 \mu \mathrm{L}, 1.22 \mu \mathrm{mol})$ were reacted in anhydrous chloroform $(70 \mathrm{~mL})$ at $50{ }^{\circ} \mathrm{C}$ for $6 \mathrm{~h}$ and then treated as above to give the tris-urea 7 (246 $\mathrm{mg}, 96 \%$ ) as a colorless, amorphous solid, mp $321{ }^{\circ} \mathrm{C}$; IR (KBr): $v=3397,3064,1682,1631,1598$,
1542, 1498, 1441, 1351, 1311, 1237, 751, 692, $663 \mathrm{~cm}^{-1}$; ${ }^{1} \mathrm{H}$ NMR (500 MHz, DMSO- $d_{6}$ ), see Supporting Information File 1 for $600 \mathrm{MHz}$ spectrum: $\delta=8.86(\mathrm{~s}, 3 \mathrm{H}), 7.56$ and 7.24 $\left(A A^{\prime} B B^{\prime}, 12 \mathrm{H}\right), 7.28(\mathrm{~d}, J=7.9 \mathrm{~Hz}, 6 \mathrm{H}), 7.15(\mathrm{t}, J=7.7 \mathrm{~Hz}$, $6 \mathrm{H}), 6.84(\mathrm{t}, J=7.4 \mathrm{~Hz}, 3 \mathrm{H}), 6.80(\mathrm{~s}, 3 \mathrm{H}), 1.62(\mathrm{~s}, 3 \mathrm{H})$; ${ }^{13} \mathrm{C}$ NMR (125 MHz, DMSO- $d_{6}$ ): $\delta=154.2,144.6,140.4$ (all C), 128.6, 128.3, 123.5, 120.9, $117.3($ all CH), 77.1 (C), 76.9 (C), $12.9\left(\mathrm{CH}_{3}\right) ;{ }^{1} \mathrm{H} \mathrm{NMR}\left(500 \mathrm{MHz}, \mathrm{C}_{2} \mathrm{D}_{2} \mathrm{Cl}_{4}, 120{ }^{\circ} \mathrm{C}\right): \delta=$ 7.49 and $7.26\left(A A^{\prime} B B^{\prime}, 12 \mathrm{H}\right), 7.17$ (br s, 12H), $7.00(\mathrm{~m}, 3 \mathrm{H})$, $6.57(\mathrm{~s}, 3 \mathrm{H}), 5.37(\mathrm{~s}, 3 \mathrm{H}), 1.71(\mathrm{~s}, 3 \mathrm{H})$; MS [FAB(+), NBA] $m / z(\%): 1394(2)[2 \mathrm{M}+\mathrm{H}]^{+}, 697(100)[\mathrm{M}+\mathrm{H}]^{+}, 561(78)$, 426 (14); MS [ESI(+), MeOH] $m / z(\%): 1415.7$ (2) $[2 \mathrm{M}+$ $\mathrm{Na}]^{+}, 1394.6(1), 1274.6$ (1), 1072.9 (1), 719.2 (100) $[\mathrm{M}+\mathrm{Na}]^{+}, 697.3(7), 561.2$ (15); MS [ESI(+), MeOH, $\left.\left.\left(\mathrm{CH}_{3}\right)_{4} \mathrm{NPF}_{6}\right)\right] \mathrm{m} / z(\%): 1467.7(1)\left[2 \mathrm{M}+\left(\mathrm{CH}_{3}\right)_{4} \mathrm{~N}\right]^{+}, 1416.7$ (1), 1393.7 (1), $770.3(20)\left[\mathrm{M}+\left(\mathrm{CH}_{3}\right)_{4} \mathrm{~N}\right]^{+}, 719.2(100), 697.3$ (52), 561.2 (90); combustional analysis: $\mathrm{C}_{44} \mathrm{H}_{36} \mathrm{~N}_{6} \mathrm{O}_{3}$ calcd $\mathrm{C}$ 75.84, H 5.21, N 12.06, found C 75.72, H 5.44, N 12.09; accurate mass $[\operatorname{ESI}(+)]:\left[\mathrm{C}_{44} \mathrm{H}_{36} \mathrm{~N}_{6} \mathrm{O}_{3} \mathrm{Na}\right]^{+}$calcd 719.2747 , found 719.2728 .

\section{Supporting Information}

\section{Supporting Information File 1}

${ }^{1} \mathrm{H}$ NMR spectra including magnifications of compounds $\mathbf{5}$, 6 and $7(600 \mathrm{MHz})$ and of compounds 8, 9, 10 and 11 (500 $\mathrm{MHz})$.

[http://www.beilstein-journals.org/bjoc/content/ supplementary/1860-5397-7-43-S1.pdf]

\section{Acknowledgements}

We would like to thank Dr. H. Luftmann, University of Münster, and Dr. M. Letzel, Bielefeld University, for recording the ESI mass spectra of compounds 5-7.

\section{References}

1. Kuck, D. Chem. Rev. 2006, 106, 4885-4925. doi:10.1021/cr050546+

2. Zhang, T. X.; Zhou, L.; Cao, X. P.; Kuck, D. Chin. J. Org. Chem. 2007, 27, 946-957.

3. Haag, R.; Ohlhorst, B.; Noltemeyer, M.; Fleischer, R.; Stahlke, D.; Schuster, A.; Kuck, D.; de Meijere, A. J. Am. Chem. Soc. 1995, 117, 10474-10485. doi:10.1021/ja00147a009

4. Kuck, D.; Schuster, A.; Krause, R. A.; Tellenbröker, J.; Exner, C. P.; Penk, M.; Bögge, H.; Müller, A. Tetrahedron 2001, 57, 3587-3613. doi:10.1016/S0040-4020(01)00246-0

5. Niu, W. X.; Wang, T.; Hou, Q. Q.; Li, Z. Y.; Cao, X. P.; Kuck, D. J. Org. Chem. 2010, 75, 6704-6707. doi:10.1021/jo101106k

6. Wang, T.; Hou, Q. Q.; Teng, Q. F.; Yao, X. J.; Niu, W. X.; Cao, X. P.; Kuck, D. Chem.-Eur. J. 2010, 16, 12412-12424. doi:10.1002/chem.201001620

7. Mughal, E. U.; Kuck, D. Org. Biomol. Chem. 2010, 8, 5383-5389. doi:10.1039/c0ob00337a 
8. Scheerder, J.; Fochi, M.; Engbersen, J. F. J.; Reinhoudt, D. N. J. Org. Chem. 1994, 59, 7815-7820. doi:10.1021/jo00104a044

9. Scheerder, J.; Engbersen, J. F. J.; Casnati, A.; Ungaro, R.; Reinhoudt, D. N. J. Org. Chem. 1995, 60, 6448-6454. doi:10.1021/jo00125a035

10. Mogck, O.; Böhmer, V.; Vogt, W. Tetrahedron 1996, 52, 8489-8496. doi:10.1016/0040-4020(96)00404-8

11. Casnati, A.; Fochi, M.; Minari, P.; Pochini, A.; Reggiani, M.; Ungaro, R.; Reinhoudt, D. N. Gazz. Chim. Ital. 1996, 126, 99-106.

12. Hamann, B. C.; Shimizu, K. D.; Rebek, J., Jr. Angew. Chem., Int. Ed. Engl. 1996, 108, 1425-1427. doi:10.1002/anie.199613261

13. Schalley, C. A.; Castellano, R. K.; Brody, M. S.; Rudkevich, D. M.; Siuzdak, G.; Rebek, J., Jr. J. Am. Chem. Soc. 1999, 121, 4568-4579. doi:10.1021/ja990276a

14. Snellink-Ruel, B. H. M.; Antonisse, M. M. G.; Engbersen, J. F. J.; Timmerman, P.; Reinhoudt, D. N. Eur. J. Org. Chem. 2000, 165-170. doi:10.1002/(SICI)1099-0690(200001)2000:1<165::AID-EJOC165>3.0. CO;2-\#

15. Reinoso-Garcia, M. M.; Dijkman, A.; Verboom, W.; Reinhoudt, D. N.; Malinowska, E.; Wojciechowska, D.; Pietrzak, M.; Selucky, P. Eur. J. Org. Chem. 2005, 2131-2138. doi:10.1002/ejoc.200500002

16. Collet, A. Tetrahedron 1987, 43, 5725-5759. doi:10.1016/S0040-4020(01)87780-2

17. Collet, A.; Dutasta, J. P.; Lozach, B.; Canceill, J. Top. Curr. Chem. 1993, 165, 103-129. doi:10.1007/BFb0111282

18. Schmuck, C.; Wienand, W. Synthesis 2002, 655-663. doi:10.1055/s-2002-23541

19. Brotin, T.; Dutasta, J. P. Chem. Rev. 2009, 109, 88-130. doi:10.1021/cr0680437

20. Tellenbröker, J.; Kuck, D. Angew. Chem., Int. Ed. 1999, 111, 1000-1004. doi:10.1002/(SICI)1521-3773(19990401)38:7<919::AID-ANIE919>3.0. $\mathrm{CO} ; 2-\mathrm{O}$

21. Spitzer, U. A.; Steward, R. J. Org. Chem. 1974, 39, 3936-3937. doi:10.1021/jo00940a031

22. Strübe, J.; Neumann, B.; Stammler, H. G.; Kuck, D. Chem.-Eur. J. 2009, 15, 2256-2260. doi:10.1002/chem.200802371

23. Hirashima, T.; Manabe, O. Chem. Lett. 1975, 4, 259-260. doi:10.1246/cl.1975.259

24. Kohne, B.; Praefcke, K.; Derz, T.; Gondro, T.; Frolow, F. Angew. Chem., Int. Ed. Engl. 1986, 98, 627-628. doi:10.1002/anie.198606501

25. Kohne, B.; Praefcke, K. Liebigs Ann. Chem. 1987, 265. doi:10.1002/jlac.198719870319

\section{License and Terms}

This is an Open Access article under the terms of the Creative Commons Attribution License

(http://creativecommons.org/licenses/by/2.0), which permits unrestricted use, distribution, and reproduction in any medium, provided the original work is properly cited.

The license is subject to the Beilstein Journal of Organic Chemistry terms and conditions:

(http://www.beilstein-journals.org/bjoc)

The definitive version of this article is the electronic one which can be found at: doi:10.3762/bjoc. 7.43 